Digital Empowerment of Students in Universities 


\title{
EDUCATION
}

LWATI: A Journal of Contemporary Research, 7(3), 1-10, 2010

ISSN: $1813-2227$

UAS

\section{Digital Empowerment of Students in Universities in the South-Eastern Zone of Nigeria}

\author{
Eyiuche Ifeoma Olibie, Lillian-Rita Ifeoma Akudolu and Wenceslaus Ofojebe \\ Utchac Educational Konsults, 35a New Market Road, Onitsha - Nigeria \\ E-Mail:utchakonsults@yahoo.co.uk. \\ Department of Educational Foundations, Nnamdi Azikiwe University, \\ Awka - Nigeria \\ E-Mail:lilianrita2003@hotmail.com \\ Department of Educational Foundations/ Administration \\ Nwafor Orizu College of Education, Nsugbe, Anambra State - Nigeria \\ E-Mail:frwence@yahoo.com
}

\begin{abstract}
The digital empowerment of the information society is related to whether or not one has the capacity to use information technology and its contents, and whether or not one could maximize the possibilities of information technology to participate meaningfully in society. This paper investigated the extent of digital empowerment of university students in South East Zone of Nigeria. Four research questions were used. Simple random sampling technique was used to select 1,125 year two students for the study. A 60 -item questionnaire was used to collect data which was analyzed using mean and standard deviation. Findings indicate the students were aware of the empowering potentials of digital technologies and were motivated to be digitally empowered. However, technical access and competencies in digital technologies were lacking, implying that the prerequisites for digital empowerment of youths (awareness, motivation, technical access, and competence) were inadequate. Some recommendations for digital empowerment of university students were made.
\end{abstract}

\section{INTRODUCTION}

Digital empowerment implies the abilities of people to use information technology and the Internet to improve their life-skills and strengthen their capabilities in the information society. This empowerment can happen in Universities, for instance, when students improve their skills and knowledge, learn to share information, create new and diverse information flows, and increase their interaction and ways of participation in information highways (United Nations Economic and Social Commission for Asia and the Pacific, 
2000). A student is said to be digitally empowered when he/she have in-depth awareness, competence, and knowledge to participate in computer operating systems, Internet, mailing lists, web logs, online publishing systems, WikiWikiWeb-techniques or common www-publishing formats, digital cameras, cell-phones, digital television, and interactive audios, among others. With digital empowerment, students gain new abilities and ways to participate and express themselves in a networked information technology driven society (Webster, 2000; Norris, 2001). Being digitally empowered is likely to influence a youth's future pathways since it is generally considered to be an essential requirement for access to the desirable labour market (Legris, Ingham, \& Collerette, 2003). In addition, it is a stepping stone for lifelong learning (Blair, 2002;Ikediugwu, 2008). Not only does digital empowerment affect the ability of individuals to compete in the labour market, it also affects the types of jobs they obtain, the status they attain and the wages they receive. Without digital empowerment of youths, Nigeria would remain very short of future personnel who can manage modern competitive enterprises and run sophisticated technologies.

Digital Youth Empowerment is predicated on the assumption young people must be allowed to, and encouraged to, participate in the decisionmaking processes, which affect their lives using digital technology (Astin, 2000, Thatcher, \& Oliver, 2001). Not only is this their right, but also it will encourage young people to become more responsible citizens. For Mäkinen (2006) digital empowerment is an enabling process, which proceeds like a spiral on four components of: awareness, motivation, technical access and competence. Awareness refers to understanding the potential opportunities of using any new technology, like the Internet. Motivation also is an essential element in all kinds of learning and development. Pew Internet and American Life Project (2003) argued that both awareness and motivation are often as critical variables as technical access while making decisions to use or not to use the Internet. Technical access refers to both the hardware and software needed for accessing the Internet (Creighton, 2001). However, having technical access does not mean that the technology is being used if there is no competence for its use. Competence refers to the skills and abilities to use new information technology (IT). It also involves the possession of digital literacy to understand IT messages. When these four elements are in place, one would expect a possibility for constructive participation in a technologically-driven world.

Digital empowerment is not just about acquiring basic ICT skills like the use of cell-phones, e-mails, and word processing (Mbakwem, 2008). It also requires students' abilities to improve their abilities of being connected to widening social networks, technical skills, receiving and producing information, and learning new ways to act and participate in civic life by using information technology (Creighton, 2001; Blair, 2002). Through the "endorsement of knowledge management for youth digital empowerment, universities can evolve from bureaucracies to educational knowledge economies, empowering their students to compete in networked information 
driven global society" (Petrides \& Guiney, 2002:1703). As stated by Coppieters (2005:134), "digital learning depends on the motivation of the agents to stimulate the flow of information and increase change". By implication, students needs to be motivated, aware and competently use digital technology for data collection, information analysis, and learned knowledge to be effective e-citizens.

\section{Statement of the Problem}

One is worried that the extent of digital empowerment of Nigerian students has not been as impressive as expected (Okebukola, 2006). Although all the universities in the South-East Zone of Nigeria have made ICT literacy compulsory for students, many university students appear not to reap the potentials of digital technology to transform their knowledge and life-coping skills. While several kinds of affordable technology are arriving in universities via digital wireless connections or digital radio, little is known about the extent to which university students have become empowered in terms of digital awareness, motivation, technical access and competency. The purpose of this study is therefore to find out the extent of digital empowerment of university students in South-East Zone of Nigeria.

\section{Research Questions}

The study was based on four research questions as follows:

1. To what extent are students in universities in South East Zone of Nigeria aware of the empowering potentials of digital technologies?

2. To what extent are the students motivated for digital empowerment?

3. To what extent do the students have technical access to digital technologies?

To what extent do the students possess the competencies for digital empowerment?

\section{Research Design}

The descriptive survey research design was adopted for this study. This design was appropriate because it elicited and analysed information from a sample of university students on their digital empowerment.

\section{Area of the Study}

The study was carried out in all government-owned universities in SouthEast zone of Nigeria. The Zone comprised five states: Abia, Anambra, Ebonyi, Enugu and Imo States. There were nine government-owned universities in South-East zone of Nigeria as at March 2008. The Federal government owned four of the universities while State governments owned five. 


\section{Population for the Study}

The population for this study consist of all the second year students in the nine government-owned universities in the South East zone of Nigeria. Second year students were chosen because they have done the compulsory courses and training in ICT and are in a position to say the say the extent to which they have been digitally empowered.

\section{Sample and Sampling Technique}

The sample comprised 1,125 respondents selected through simple random sampling. In each of the nine universities, five faculties were randomly selected. From each of the selected faculties, five departments $(n=225)$ were randomly selected. Simple random sampling was then used to pick five students from each of the five departments, thus bringing a researcher developed the total sample size to 1,125 students.

\section{Instrument for Data Collection}

The instrument used in this study was questionnaire titled - "Questionnaire on Digital Empowerment of University Students (QDEVS)". The QDEVS comprised 60 items in four sections. The items were structured on a 4-point rating scale of Very High Extent, High Extent, Low Extent and Very Low Extent.

\section{Validation of the Instrument}

Using the research questions and purpose of study, two lecturers from the Faculty of Education in Nnamdi Azikiwe University, Awka, validated an initial draft of the questionnaire that contained 65 items. Based on their corrections, 60 items were finally used for the study.

\section{Reliability of the Instrument}

The researchers administered copies of the questionnaire on twenty (20) year two students from Delta State State University Abraka, whose responses were analysed using the Cronbach Alpha Method. Using the SPSS version 13.5, reliability coefficients of $0.87,0.86,0.85$ and 0.80 were obtained for the four sections of the questionnaire respectively. These coefficients were high enough for the instrument to be considered reliable for use in the study.

\section{Administration of Instrument}

Copies of the questionnaire were administered with the help of nine research assistant who were students in the universities. Out of the 1125 copies 
distributed, only 1093 were retrieved. The percentage return rate was 97.15 percent.

\section{Method of Data Analysis}

Mean and standard deviation scores were used to answer the research question. To enhance computation, the options were weighted on the 4-point rating scale thus Very High Extent (VHE, 4 points), High extent (HE, 3 points), Low Extent (LE, 2 points) and Very Low Extent (VLE, 1 point). The midpoint for the scale is 2.5 obtained thus: $=4+3+2+1=10.10 / 4=2.5$.

For decision-making Very High Extent and High Extent were merged to become High Extent while Low Extent and Very Low Extent were merged to become low extent. Items with mean above 2.50 represent high extent while those with mean below 2.50 represent low extent.

\section{Presentation and Analysis of Data}

The data collected in respect of the four research questions are presented in tables 1 to 4 .

Table 1: Means and standard deviations of students on digital awareness $(\mathrm{N}=1093)$.

\begin{tabular}{|c|c|c|c|c|}
\hline \multirow{2}{*}{$\begin{array}{l}\text { Item } \\
\text { No }\end{array}$} & \multirow[b]{2}{*}{ Digital technologies can empower one to: } & \multirow[b]{2}{*}{$\mathrm{X}$} & \multirow[b]{2}{*}{$\mathrm{Sd}$} & \multirow[b]{2}{*}{ Decision } \\
\hline & & & & \\
\hline & influence decisions on students' welfare & 2.41 & 1.39 & LE \\
\hline 2 & purchase books and items via wireless digitals & 2.94 & 1.65 & $\mathrm{HE}$ \\
\hline 3 & make money via Internet and on-line publishing & 3.21 & 1.78 & HE \\
\hline 4 & express their views and opinions in public forums & 2.00 & 1.44 & LE \\
\hline 5 & receive assistance in writing projects or term papers & 3.55 & 1.74 & $\mathrm{HE}$ \\
\hline 6 & become a motivational speaker & 3.12 & 1.49 & $\mathrm{HE}$ \\
\hline 7 & participate in scientific research and discoveries & 3.23 & 1.68 & HE \\
\hline 8 & create websites for his/her local community & 3.17 & 1.68 & $\mathrm{HE}$ \\
\hline 9 & maintain good health & 2.85 & 1.45 & HE \\
\hline 10 & improvise technology, music or art. & 3.13 & 1.51 & HE \\
\hline 11 & mould one's personality & 2.70 & 1.43 & HE \\
\hline 12 & compete with students in other countries and win prizes and awards & 3.00 & 1.79 & $\mathrm{HE}$ \\
\hline 13 & $\begin{array}{l}\text { mobilize other students to engage in community development } \\
\text { projects. }\end{array}$ & 1.11 & 1.00 & LE \\
\hline 14 & participate in political talks/ public hearing & 2.31 & 1.23 & LE \\
\hline 15 & acquire skills and insights for successful entrepreneurship. & 3.43 & 1.61 & $\mathrm{HE}$ \\
\hline 16 & widen one's creative potentials & 3.08 & 1.52 & $\mathrm{HE}$ \\
\hline 17 & create jobs for other people & 3.23 & 1.78 & HE \\
\hline 18 & identify and avoid environmental hazards & 1.11 & 1.07 & LE \\
\hline 19 & turn wastes to riches & 1.27 & 1.09 & LE \\
\hline 20 & contribute and sustain a culture of global peace & 1.15 & 1.06 & LE \\
\hline \multirow[t]{2}{*}{21} & & & & GE \\
\hline & Average mean & 2.60 & 1.47 & \\
\hline
\end{tabular}

In Table 2, seven items obtained mean ratings less than 2.50 indicating a low extent of awareness of these items, while thirteen items obtained mean ratings above 2.50 , showing a high extent of awareness of these items. The average mean for the entire items was above than 2.50. By this analysis, the 


\section{Digital Empowerment of Students in Universities}

students indicated that to a high extent, they were aware of the empowering potentials of digital technology.

Table 2: Mean and standard deviation of extent of students' motivation for digital empowerment $(\mathrm{N}=1093)$.

\begin{tabular}{|c|c|c|c|c|}
\hline $\begin{array}{l}\text { Item } \\
\text { No. }\end{array}$ & Items on digital motivation & $\overline{\mathbf{X}}$ & Sd & Decision \\
\hline 21 & I believe that I can achieve the impossible through digital technologies. & 2.78 & 1.26 & $\mathrm{HE}$ \\
\hline 22 & I look forward to using World Wide Web for new discoveries & 2.79 & 1.26 & $\mathrm{HE}$ \\
\hline 23 & I am hopeful that digital empowerment can help me to overcome my limitations. & 2.80 & 1.26 & $\mathrm{HE}$ \\
\hline 24 & I enjoy public forums in the Internet for improving my critical thinking skills. & 1.74 & 1.17 & LE \\
\hline 25 & $\begin{array}{l}\text { I am inspired to see what students in other countries are achieving with digital } \\
\text { technology }\end{array}$ & 2.73 & 1.24 & $\mathrm{HE}$ \\
\hline 26 & I wish I can use digital technologies to improve my community & 3.55 & 1.65 & HE \\
\hline 27 & With digital empowerment, I will do well in life. & 3.08 & 1.43 & $\mathrm{HE}$ \\
\hline 28 & I am thrilled by the interactivity and vast information on the Internet & 2.97 & 1.36 & $\mathrm{HE}$ \\
\hline 29 & I feel happy when I download materials from the Internet for my academic work. & 3.69 & 1.69 & $\mathrm{HE}$ \\
\hline \multirow[t]{2}{*}{30} & I enjoy music from the digital audios (Mps, CD-Roms, internet, cell-phones) & 3.46 & 1.66 & $\mathrm{HE}$ \\
\hline & Average Mean & $\begin{array}{l}2 . \\
96\end{array}$ & 1.40 & HE \\
\hline
\end{tabular}

KEY: VHE = Very High extent, HE= High extent, LE = low Extent, VLE = Very Low Extent.

In Table 2, only item 24 (I enjoy public forums in the Internet for improving my critical thinking skills) obtained a mean rating below 2.50 . The rest of the items got mean ratings above 2.50 . The average mean also exceeded 2.50. Therefore, there was a high extent of students' motivation for digital empowerment in the universities.

Table 3: Mean and standard deviation of extent of students' technical access to digital technologies $(\mathrm{N}=1093)$.

\begin{tabular}{|c|c|c|c|c|}
\hline \multirow[t]{2}{*}{ Item No. } & \multirow[t]{2}{*}{ I have access to the following digital technologies: } & \multirow[b]{2}{*}{$\overline{\mathbf{X}}$} & \multirow[b]{2}{*}{ Sd } & \multirow[b]{2}{*}{ Decision } \\
\hline & & & & \\
\hline $\begin{array}{l}31 \\
32\end{array}$ & $\begin{array}{l}\text { Internet connectivitv in mv universitv } \\
\text { Satellite connection and connectivity with other networks. }\end{array}$ & $\begin{array}{l}3.50 \\
2.35\end{array}$ & $\begin{array}{l}1.63 \\
1.26\end{array}$ & $\begin{array}{l}\mathrm{HE} \\
\mathrm{LE}\end{array}$ \\
\hline $\begin{array}{l}33 \\
34 \\
35 \\
36 \\
37\end{array}$ & $\begin{array}{l}\text { ICT lecture rooms housing internet and radio-radio connection. } \\
\text { ICT resource centers, parks or cyber cafés } \\
\text { Over head projectors in lecture rooms } \\
\text { Digital andios in readino ronms } \\
\text { Laptops }\end{array}$ & $\begin{array}{l}1.97 \\
2.83 \\
1.53 \\
1.80 \\
1.72\end{array}$ & $\begin{array}{l}1.09 \\
1.27 \\
1.04 \\
115 \\
1.13\end{array}$ & $\begin{array}{l}\text { LE } \\
\text { HE } \\
\text { LE } \\
\text { IF } \\
\text { LE }\end{array}$ \\
\hline $\begin{array}{l}38 \\
39\end{array}$ & $\begin{array}{l}\text { Technical support for maintaining digital technologies } \\
\text { Campus wide Local Area Networks }\end{array}$ & $\begin{array}{l}2.16 \\
2.13\end{array}$ & $\begin{array}{l}1.18 \\
1.69\end{array}$ & $\begin{array}{l}\text { LE } \\
\text { LE }\end{array}$ \\
\hline $\begin{array}{l}40 \\
41\end{array}$ & $\begin{array}{l}\text { GSM Area Networks } \\
\text { On-line student's clubs }\end{array}$ & $\begin{array}{l}2.40 \\
2.17\end{array}$ & $\begin{array}{l}1.66 \\
1.18\end{array}$ & $\begin{array}{l}\text { LE } \\
\text { LE }\end{array}$ \\
\hline $\begin{array}{l}42 \\
43\end{array}$ & $\begin{array}{l}\text { Media player (MPs) } \\
\text { Power backups for digital technologies }\end{array}$ & $\begin{array}{l}3.56 \\
2.31\end{array}$ & $\begin{array}{l}1.67 \\
1.24\end{array}$ & $\begin{array}{l}\mathrm{HE} \\
\mathrm{LE}\end{array}$ \\
\hline $\begin{array}{l}44 \\
45\end{array}$ & $\begin{array}{l}\text { Electronic white board } \\
\text { Virtual libraries }\end{array}$ & $\begin{array}{l}0.00 \\
2.45\end{array}$ & $\begin{array}{l}0.00 \\
1.33\end{array}$ & $\begin{array}{l}\mathrm{LE} \\
\mathrm{LE}\end{array}$ \\
\hline $\begin{array}{l}46 \\
47\end{array}$ & $\begin{array}{l}\text { Instructional nackaoes in CD-ROMS } \\
\text { File back-up devices (Floppy discs, Flash drives) }\end{array}$ & $\begin{array}{l}2.44 \\
3.78\end{array}$ & $\begin{array}{l}133 \\
1.71\end{array}$ & $\begin{array}{l}\text { IF } \\
\text { HE }\end{array}$ \\
\hline $\begin{array}{l}48 \\
49\end{array}$ & $\begin{array}{l}\text { Fducational television } \\
\text { Computers }\end{array}$ & $\begin{array}{l}2.37 \\
2.46\end{array}$ & $\begin{array}{l}133 \\
1.35\end{array}$ & $\begin{array}{l}\text { IF } \\
\text { LE }\end{array}$ \\
\hline \multirow[t]{2}{*}{50} & Cable television & 1.18 & 1.13 & LE \\
\hline & Average Mean & 2.26 & 0.94 & LE \\
\hline
\end{tabular}

KEY: VHE = Very High extent, HE= High extent, LE = low Extent, VLE = Very Low Extent. 
In table 3 , only four items got mean ratings above 2.50 indicating high extent of access to the digital technologies. The remaining sixteen items had mean ratings below 2.50 indicating low extent of access. The average mean was also below 2.50. Therefore, there was a low extent of access to digital technologies among the students.

Table 4: Mean and standard deviation of extent of students' digital competencies $(\mathrm{N}=1093)$.

\begin{tabular}{|c|c|c|c|c|}
\hline \multirow[t]{2}{*}{ Item No. } & \multirow[t]{2}{*}{ I possess the ability to: } & \multirow[b]{2}{*}{$\overline{\mathbf{X}}$} & \multirow[b]{2}{*}{ Sd } & \multirow[b]{2}{*}{ Decision } \\
\hline & & & & \\
\hline 41 & navigate search engines. & 2.78 & 1.23 & $\mathrm{HE}$ \\
\hline 42 & use electronic simulations for experiments & 1.22 & 1.08 & LE \\
\hline 43 & access digital/electronic research works or projects & 2.98 & 1.28 & $\mathrm{HE}$ \\
\hline $\begin{array}{l}44 \\
45\end{array}$ & $\begin{array}{l}\text { design on-line motivational prompts using power-point. } \\
\text { use digital personality assessment inventories. }\end{array}$ & $\begin{array}{l}2.83 \\
1.06\end{array}$ & $\begin{array}{l}1.24 \\
1.01\end{array}$ & $\begin{array}{l}\text { HE } \\
\text { LE }\end{array}$ \\
\hline $\begin{array}{l}46 \\
47 \\
48\end{array}$ & $\begin{array}{l}\text { participate in Internet income generating activities } \\
\text { use data analvsis packages } \\
\text { repair digital files or podcasting }\end{array}$ & $\begin{array}{l}2.26 \\
1.53 \\
1.16\end{array}$ & $\begin{array}{l}1.18 \\
1.08 \\
1.06\end{array}$ & $\begin{array}{l}\mathrm{LE} \\
\mathrm{LE} \\
\mathrm{LE}\end{array}$ \\
\hline 49 & use GSM networks for internet connectivity & 1.03 & 0.98 & LE \\
\hline 50 & detect viruses in electronic information & 2.73 & 1.42 & $\mathrm{HE}$ \\
\hline 51 & use digital cameras to capture events & 3.13 & 1.61 & $\mathrm{HE}$ \\
\hline 52 & design community websites & 1.19 & 1.07 & LE \\
\hline 54 & participate to entrepreneurial-based Web-sites. & 1.23 & 1.00 & LE \\
\hline 54 & connect to virtual libraries & 2.44 & 1.14 & LE \\
\hline 55 & make on-line purchases & 1.25 & 1.09 & LE \\
\hline 56 & engage in on-line public forums & 2.31 & 1.28 & LE \\
\hline 57 & log on to students' resource centres & 1.17 & 1.06 & LE \\
\hline 58 & use digital technologies for youth mobilization & 2.17 & 1.18 & LE \\
\hline 59 & scan digital information for use in community enlightenment programmes & 1.06 & 1.01 & LE \\
\hline \multirow[t]{2}{*}{60} & install digital security systems & 1.34 & 1.11 & LE \\
\hline & Average Mean & 1.84 & 0.86 & LE \\
\hline
\end{tabular}

KEY: VHE = Very High extent, HE= High extent, LE = low Extent, VLE = Very Low Extent.

In Table 4, only five items got mean ratings above 2.50, indicating competence in these areas. The remaining 15 items obtained mean ratings below 2.50 indicating low levels of competencies. The average mean was 2.50 which depict low extent of digital competencies among university students in south East-Zone of Nigeria.

\section{Discussion of Findings}

The findings of this study have indicated a high extent of students' awareness of the empowering potentials of digital technologies. This finding is in line with Alabi (1996) who reported high awareness of the benefits of computer technologies selected universities in Nigeria. With the high extent of awareness, the stage has been set for students to maximize the various potentials of digital technologies which the developed countries have been enjoying. Such awareness is likely to empower students to initiate actions to bridge the digital divide.

However one is worried that the students indicated that they were unaware of the potentials of digital technologies to empower them to influence decisions on students' welfare, express their views and opinions in 
public forums, mobilize other students to engage in community development projects, participate in political talks/ public hearing ,acquire skills and insights for successful entrepreneurship, identify and avoid environmental hazards, turn wastes to riches, as well as contribute and sustain a culture of global peace. This suggests that the students were not very highly aware of the potentials of digital empowerment to their civic life. If they did not know enough about the civic empowering options or did not understand them, they might not see many reasons to apply digital technology to civic participation.

Another finding is that there was a great extent of students' motivation for digital empowerment. Since the students were aware of the empowering potentials of digital technologies, it is no surprise that they were motivated to become digitally empowered. This finding agrees with Mbakwem (2008) who found that students in universities in South East Zone of Nigeria were highly motivated to learn and use ICT. Hence, if students are to be further exposed to digital information, they might become more aware of the limitless potentials of the digital technologies and more motivated to become digitally empowered.

The issue of low extent of access to digital technologies found in this study is disturbing. This finding might be attributed to poor funding for digital technologies and IT infrastructures as observed by Ikediugwu (2008). Lack of technical assess would make students' awareness and motivation to become digitally empowered a mirage, thereby broadening the digital divide between Nigerian students and those in developed countries. As Mäkinen (2006) rightly pointed out, in the absence of a high extent of technical access, digital technologies become more unequally distributed, thus heightening the technical divides between people ties.

It was finally found that there was a low extent of students' competence in utilizing digital technologies. By indicating lack of competence in using digital technologies, university students cannot become digitally empowered to be competently involved meaningfully in the information society. This can further limit these students from bridging digital divide to become part of the networks of global communication.

\section{RECOMMENDATIONS}

The following recommendations are made based on the findings:

1) Government agencies, University management, or Students' Union Government should organize seminars and conference to intimate students more on the empowering potentials of digital technologies.

2) Universities should intensify ICT training for students. They should expose students to a range of practical tasks on digital technologies to help students become more aware and motivated for digital empowerment.

3) Students should use self-help efforts such as advanced computer training through the holidays and reading of digital journals, to become more competent in the use of digital technologies. 
4) Lecturers should facilitate digital empowerment of students. They should use available digital technologies to teach students and help them become competent in various virtual learning applications.

5) Government should invest more funds in providing digital technologies to the universities.

6) Students should also use e-learning and peer tutoring to become more competent in digital applications.

\section{CONCLUSION}

Digital empowerment is fundamental in promoting the use of technology and preparing youth to participate in a global economy. Although this study found a high extent of digital awareness and motivation among the students, technical access and competencies in digital technologies were lacking. This implies that the students have not been very highly empowered digitally, since the prerequisites for digital empowerment of youths (awareness, motivation, technical access, and competence) were inadequate. One is optimistic that given the extent of awareness and motivation among students, more efforts to improve technical access and digital competence could empower students to manipulate digital technologies and participate in global economies

\section{REFERENCES}

Ajayi, G. O. (2002, March $\left.28^{\text {th }}\right)$. Challenges to Nigeria of globalization and the information Age. Keynote Address at Workshop on the National Information Communication Infrastructure (NICI) Policy, Plans and strategies for Implementation. Held at National Universities Commission (NUC) Auditorium, Aguiyi Ironsi Street, Maitama, Abuja.

Alabi, G. A. (1996). Empowering socio-economic development in Africa utilizing information technology a critical examination of the social, economic, technical and policy issues in Nigeria. Retrieved on $24^{\text {th }}$ July 2008 from www. african information society initiative.html.

Atkins, R. (2000). Civic competence in urban youth. Applied Developmental Science, 6(4), 227-236.

Blair, D. C. (2002). Knowledge management: Hype, hope, or help? Journal of the American Society for Information Science and Technology,53(12), 1019-1028.

Coppieters, P. (2005). Turning schools into learning organizations. European Journal of Teacher Education,28(2), 129-139.

Creighton, T. B. (2001). Data analysis in administrators' hands: An oxymoron. Retrieved September 23, 2007, from http://www.aasa.org/publications/sa/200104/ creighton.html 


\section{Digital Empowerment of Students in Universities}

Flanagan, C. \& Faison, N. (2001). Youth civic development: Implications of research for social policy and programs, Social Policy Report, 15(1). Ann Arbor, MI: Society for Research in Child Development.

Ikedigwu, N. (2008). Challeges in information technology. In B. G. Nworgu (Ed). Education in the information age: global Challenges and enhancement strategies. Pp Pp 345-349 Nsukka: University Trust Publishers.

Legris, P., Ingham, J., \& Collerette, P. (2003). Why do people use information technology? A critical review of the technology acceptance model. Information and Management 40, 191-204

Mäkinen, M (2006). Digital empowerment as a process for enhancing citizens participation. Retrieved on $18^{\text {th }}$ May 2008 from http://www.globaledevelopment.org/papers/maarit.eDeve.pdf.

Mbakwem, J. N. (2008). Analysis of university undergraduate students' and lecturers' need for the information age; implications for teaching and learning. In B. G. Nworgu (Ed). Education in the information age: global Challenges and enhancement strategies. Pp 208-213. Nsukka: University Trust Publishers.

Norris, P. (2001) Digital divide? engagement, information poverty and the internet worldwide. Cambridge University Press.

Okebukola, P. (2006). VLIR: the structural collaboration of Nigerian Tertiary institutions in view of quality control. Retrieved on 26th November 2006 from http://www.vlir.be/virtual-clearinghouse// higher education $/ / \mathrm{html}$.

Petrides, L. A., \& Guiney, S. Z. (2002). Knowledge management for school leaders: ecological framework for thinking schools. Teachers College Record,104(8), 1702-1717.

Thatcher, M. E., \& Oliver, J. R. (2001). The impact of technology investments on firm's production efficiency, product quality, and productivity. Journal of Management Information Systems,18(2), $17-45$.

The Pew Internet and American Life Project (2003). Life surveys in 19952000 and 2003. Retrieved on $23^{\text {rd }}$ July 2008 from www.pewinternet.org.

United Nations Economic and Social Commission for Asia and the Pacific (2000). HRD for youth empowerment : Eight innovative approaches submitted for the 1999 ESCAP HRD Award. Retrieved on $24^{\text {th }}$ June 2008 from http://www.unescap.org/esid/hds /practices/youth/hrdaw99.doc.

Webster, F. (2000). Theories of the Information Society. London and New York: Routledge

Youniss, J. (1999). Civic development and community service. Paper presented at Creating citizenship: Youth development for free and democratic society, Stanford University. Retrieved on $18^{\text {th }}$ May 2008 from www.stanford.edu/group/adolescent.ctr/ Conference/Panel/youniss.html. 